\title{
PHOSPHOTYROSINE-PROTEIN-PHOSPHATASES AND HUMAN REPRODUCTION: AN ASSOCIATION BETWEEN LOW MOLECULAR WEIGHT ACID PHOSPHATASE (ACP1) AND SPONTANEOUS ABORTION
}

\author{
F. GLORIA-BOTTINI*, M. NICOTRA $§$, N. LUCARINI ${ }^{\dagger}$, P. BORGIANI*, M. LA TORRE ${ }^{\ddagger}$, \\ A. AMANTE* ${ }^{*}$ A. GIMELFARB ${ }^{\mathbb{I l}}$ AND E. BOTTINI ${ }^{*}$ \\ *Chair of Preventive Pediatrics, 2nd University of Rome-Torvergata, School of Medicine, Rome, Italy \\ $\$$ Department of Obstetrics and Gynecology, lst University of Rome, School of Medicine, Rome, Italy \\ ${ }^{\dagger}$ Laboratory of Genetics, University of Camerino School of Science, Camerino, Italy \\ $\doteqdot$ Department of Pediatrics, USSL Penne, Italy \\ IlDepartment of Ecology and Evolution, University of Chicago, Chicago, USA.
}

\begin{abstract}
SUMMARY
ACP1 (low molecular weight acid phosphatase) genetic polymorphism has been studied in 173 women with a history of two or more consecutive spontaneous abortions and in 1508 control subjects, including 482 normal pregnant women. The proportion of carriers of ACP $1 * \mathrm{C}$ allele $(* \mathrm{~A} /$ $* \mathrm{C}, * \mathrm{~B} / * \mathrm{C}$ ) in women with a history of repeated spontaneous abortion is lower than in normal pregnant women and other control groups. Women with repeated spontaneous abortion show a specific decrease of ACP1 S isoform concentration as compared to normal pregnant women. The other component of ACP1 activity, the F isoform, does not show a significant difference between the two groups. The data suggest that women with ACP1 genotypes showing a high concentration of S isoform are relatively 'protected' against spontaneous abortion. Preliminary analysis of a sample of 352 normal puerperae along with their newborn babies supports this hypothesis.
\end{abstract}

KEY wORDS ACP1 PTPases Habitual abortion Human reproduction

\section{INTRODUCTION}

Approximately $75 \%$ of embryos are lost during the early stages of intrauterine life (Diamond, 1987; Boklage, 1990). Both environmental and genetic factors are probably important determinants of such a high mortality, and it is likely that their effects are amplified by genomic instability during the early life stages (Vogel and Motulsky, 1986; Hicks, 1987). It is quite possible that common genetic polymorphisms play an important role in this process of intrauterine selection.

There has been a substantial interest recently in protein-tyrosine-phosphatases (PTPases) which may influence the action of growth factors through the regulation of phosphorylation state of critical target proteins (Goldstein, 1992; Fischer et al., 1991).

Correspondence to: Egidio Bottini, MD, Cattedra di Pediatrica Preventiva Sociale, Dipartimento di Chirurgia, Università di Roma-Torvergata, Via di Tor Vergata, 135, 00173 Roma, Italy. Tel./Fax 39-6-72596028 or 72596030 . 
One such PTPase is the highly polymorphic low molecular weight acid phosphatase (ACP1). In fact, recent experimental evidence indicates that $\mathrm{ACP} 1$ is able to dephosphorylate growth factor receptors (Stefani et al., 1993). This enzyme is controlled by a locus on chromosome 2 having three common alleles: $\mathrm{ACP} 1 * \mathrm{~A}, \mathrm{ACP} 1 * \mathrm{~B}$ and $\mathrm{ACP} 1 * \mathrm{C}$. There are quantitative differences in the enzymatic activity among ACP1 genotypes. Spencer et al. (1964) have found the following order of allelic contributions to the enzymatic activity: $\mathrm{ACP} 1 * \mathrm{~A}<\mathrm{ACP} 1 * \mathrm{~B}<\mathrm{ACP} 1 * \mathrm{C}$.

ACP1 is a member of a family of low molecular weight acid phosphatases that are found in human erythrocytes, in the rat liver and in other human and animal tissues. The animal enzymes have sequencies similar to the human ACP1 (Wo et al., 1992; Camici et al., 1989; Dissing and Svensmark, 1990; Dissing et al., 1991; Manao et al., 1992). Two important functions of $\mathrm{ACP} 1$ have been suggested based on the experimental evidence: flavin-phosphatase activity and tyrosine phosphatase activity (Wo et al., 1992; Boivin and Galand, 1986; Mansfield and Sensabaugh 1978; Fuchs et al., 1992). By catalysing the conversion of flavin-mononucleotide (FMN) to riboflavin, ACP1 may play a role in regulating the cellular concentration of flavin-adenin-dinucleotide (FAD), flavoenzyme activity and energy metabolism. As phosphotyrosine phosphatase (PTPase), the enzyme may affect the cellular growth regulation and the modulation of glycolytic rate by controlling receptor activities (Wo et al., 1992; Boivin and Galand, 1986; Ramponi et al., 1989; Ramponi et al., 1992: Vogel et al., 1993). Given that activity variants of ACP1 are common, it is possible that this enzyme is important in regulating a large spectrum of cellular functions.

Each allele of ACP1 locus encodes two isozymes, the fast $(\mathrm{F})$ and the slow $(\mathrm{S})$ that are expressed in an allele specific ratio: $\mathrm{F} / \mathrm{S}=2: 1,4: 1$ and 1:4 for $\mathrm{ACP} 1 * \mathrm{~A},{ }^{*} \mathrm{~B}$ and $* \mathrm{C}$ allele, respectively (Dissing, 1987). Significant differences between F and S isozymes have been observed in both enzymatic and molecular properties suggesting that $\mathrm{F}$ and $\mathrm{S}$ isozymes may serve different biological functions in the cell (Stefani et al., 1993). On the other hand, the three genetically different $\mathrm{F}$ isozymes (Af, Bf, Cf) show identical properties as do the three $S$ isozymes (Dissing, 1987). Thus, from a functional point of view, the common ACP1 phenotypes consist of only two different isozymes, F and S, the proportion of which determines the properties of the phenotypes.

Associations of ACP1 genotype with developmental parameters (Amante et al., 1990), congenital malformations (Ward et al., 1986) and fertility parameters (Chakraborty et al., 1986) have been reported, all pointing to a significant role of ACP1 in human reproduction. In the current note, we present an analysis of data suggesting an association between ACP1 genotype and spontaneous abortion.

\section{MATERIALS AND METHODS}

\section{Women with repeated spontaneous abortions}

173 women who had at least two consecutive spontaneous abortions were examined. This condition is currently clinically classified as 'habitual abortion'. All the subjects were seen at the Center for Reproductive Disorders of the Department of Obstetrics and Gynecology at the 1st University of Rome. All couples wanted to have a child and requested medical assistance in general after the second or third episode of miscarriage but in some instances after the first episode. The following clinical examinations and tests are generally performed on a couple after two consecutive abortions: hysterosalpingo- 
graphy, a study of the cycle with the registration of the basic temperature and the serial determination of the serum progesterone levels during the luteinic phase, glucose tolerance test, serological tests for lues and a test for Toxoplasma infection. At least three examinations of the seminal liquid are also performed. All of the clinical examinations and tests described above were consistently negative in the subjects included in the present sample. A standard karyotype analysis is also performed routinely in couples with habitual abortion.

\section{Controls}

\section{Normal pregnant women}

ACP1 genotypes were evaluated in three consecutive samples of women delivering a single live-born infant. Two of the samples were collected from the population of Rome, and one from the population of Penne, a small town in the Central-Eastern part of Italy. The distributions of ACP1 genotypes in the three samples were not significantly different, and the samples were combined into a single data set (Table 1).

\section{Newborn infants}

ACP1 genotype was determined in a consecutive sample of 608 newborn infants of both sexes from the population of Rome.

\section{Normal adults}

417 adults (both sexes) from the population of Rome previously studied by Modiano et al. (1967) were also considered as controls.

ACPl genotype was determined according to Harris and Hopkinson (1976). F and S isoform concentrations were assigned to each genotype according to Dissing (1987).

Statistical analyses were carried out using SPSS programs (Nie et al., 1975) on an IBM PC.

\section{RESULTS}

Table 1 shows the distribution of ACP1 genotypes in women with habitual abortions, in their husbands and in controls. The proportion of genotypes carrying the ACP $1 * \mathrm{C}$ allele is lower in women with habitual abortion than in normal pregnant women, in husbands or in other normal controls. No statistically significant difference is observed between normal controls and normal pregnant women or husbands of women with habitual abortion. Reliable negative history of spontaneous abortion was obtained in 259 normal pregnant women. Compared with these subjects, women with habitual abortion again show a lower frequency of genotypes carrying the ACP1*C allele. No significant difference is observed between women with two consecutive spontaneous abortions and women with three or more consecutive abortions. No significant association has been observed between ACP1 distribution and age in normal pregnant women. The proportion $\mathrm{ACP} 1 * \mathrm{C}$ carriers is $12,8 \%$ in women less than 28 years old and $11,96 \%$ in women more than 28 years old.

Table 2 shows the mean concentration of F and S ACP1 isoforms in women with habitual abortion and in normal pregnant women. A highly significant difference is observed in the $\mathrm{S}$ isoform concentration: the mean value is lower in women with habitual abortion than in normal pregnant women. On the other hand, the concentration of $\mathrm{F}$ isoform does not show a significant difference between the two samples. 
Table 1. ACP1 distribution (per cent) in women with repeated spontaneous abortion and in control subjects.

\begin{tabular}{|c|c|c|c|c|c|c|c|c|c|c|c|}
\hline & \multirow[b]{2}{*}{$* \mathrm{~A} / * \mathrm{~A}$} & \multicolumn{5}{|c|}{ ACP1 genotypes } & \multicolumn{5}{|c|}{ ACP1 alleles } \\
\hline & & $* \mathrm{~B} /{ }^{*} \mathrm{~B}$ & $* \mathrm{C} / * \mathrm{C}$ & $* \mathrm{~A} /{ }^{*} \mathrm{~B}$ & $* \mathrm{~A} / * \mathrm{C}$ & $* \mathrm{~B} / * \mathrm{C}$ & total no. & $* \mathrm{~A}$ & $* \mathrm{~B}$ & $* \mathrm{C}$ & total no. \\
\hline \multicolumn{12}{|l|}{$\begin{array}{l}\text { Women with repeated } \\
\text { spontaneous abortions }\end{array}$} \\
\hline All (1) & $10.4 \%$ & $43.4 \%$ & $0.0 \%$ & $41.0 \%$ & $0.6 \%$ & $4.6 \%$ & 173 & $31.2 \%$ & $66.2 \%$ & $2.6 \%$ & 346 \\
\hline 2 abortions ( $1 \mathrm{a}$ ) & $8.4 \%$ & $49.4 \%$ & $0.0 \%$ & $37.4 \%$ & $0.0 \%$ & $4.8 \%$ & 83 & $27.1 \%$ & $70.5 \%$ & $2.4 \%$ & 166 \\
\hline 3 or more abortions $(1 b)$ & $12.2 \%$ & $37.8 \%$ & $0.0 \%$ & $44.4 \%$ & $1.1 \%$ & $4.4 \%$ & 90 & $35.0 \%$ & $62.2 \%$ & $2.8 \%$ & 180 \\
\hline Husbands (2) & $4.1 \%$ & $49.1 \%$ & $0.0 \%$ & $33.1 \%$ & $4.1 \%$ & $9.5 \%$ & 169 & $22.8 \%$ & $70.4 \%$ & $6.8 \%$ & 338 \\
\hline \multicolumn{12}{|l|}{ Normal pregnant women } \\
\hline All (3) & $8.3 \%$ & $40.7 \%$ & $0.0 \%$ & $38.4 \%$ & $3.3 \%$ & $9.3 \%$ & 482 & $29.2 \%$ & $64.5 \%$ & $6.3 \%$ & 964 \\
\hline $\begin{array}{l}\text { With negative history } \\
\text { of abortion ( } 3 \mathrm{a})\end{array}$ & $7.7 \%$ & $39.0 \%$ & $0.0 \%$ & $41.3 \%$ & $2.7 \%$ & $9.3 \%$ & 259 & $29.7 \%$ & $64.3 \%$ & $6.0 \%$ & 518 \\
\hline $\begin{array}{l}\text { Consecutive newborn babies } \\
\text { (both sexes) (4) }\end{array}$ & $9.5 \%$ & $46.3 \%$ & $0.5 \%$ & $31.2 \%$ & $3.1 \%$ & $9.4 \%$ & 609 & $26.7 \%$ & $66.6 \%$ & $6.7 \%$ & 1218 \\
\hline $\begin{array}{l}\text { Normal adults } \\
\qquad \text { (both sexes) (5) }\end{array}$ & $8.6 \%$ & $43.9 \%$ & $0.2 \%$ & $31.6 \%$ & $3.4 \%$ & $12.2 \%$ & 417 & $26.1 \%$ & $65.8 \%$ & $8.0 \%$ & 834 \\
\hline
\end{tabular}

Chi square test of independence

$\begin{array}{ll}(1) \operatorname{vs}(2) \operatorname{vs}(3) \operatorname{vs}(4) \operatorname{vs}(5) & \mathrm{p}=0,0099 \\ (4) \operatorname{vs}(5) & \mathrm{p}=0,5769 \\ (1) \operatorname{vs}(3) & \mathrm{p}=0,0524 \\ (1) \operatorname{vs}(4+5) & \mathrm{p}=0,0032 \\ (2) \operatorname{vs}(4+5) & \mathrm{p}=0,1755 \\ (3) \operatorname{vs}(4+5) & \mathrm{p}=0,0658 \\ (1 \mathrm{a}) \operatorname{vs}(1 \mathrm{~b}) & \mathrm{p}=0,4786 \\ (1) \operatorname{vs}(3 \mathrm{a}) & \mathrm{p}=0,0911\end{array}$

0,0144
0,2308
0,0099
0,0018
0,9507
0,4849
0,9007
0,0272

0,0173

0,3034

0,0122

0,0018

0,8514

0,3884

0,9020

0,0312 
Table 2. F and S ACP1 isoform concentration in women with repeated spontaneous abortion and in normal puerperae.

\begin{tabular}{lccccc}
\hline & \multicolumn{2}{c}{ F isoform } & \multicolumn{2}{c}{ S isoform } & no. of women \\
& mean & S.D. & mean & S.D. & \\
\hline $\begin{array}{l}\text { Women with repeated } \\
\text { spontaneous abortion }\end{array}$ & 13.43 & 2.9 & 4.08 & 1.9 & 173 \\
$\begin{array}{l}\text { Normal puerperae } \\
\text { Significance of difference }\end{array}$ & 13.23 & 2.9 & 4.72 & 2.9 & 482 \\
(two tail) & $\mathrm{p}=0.451$ & $\mathrm{p}=0.002$ & \\
\hline
\end{tabular}

Table 3 shows the ratio of females carrying $* \mathrm{C}$ allele to females not carrying this allele in relation to the carrier status of their husbands. The proportion of $* \mathrm{C}$ carriers is much lower among women with a non carrier husband than among women with a carrier husband.

Table 4 shows the observed and expected distributions of ACP1 mating types (assuming control parameters and random mating). There is a strong reduction of mating types [female carrying $* \mathrm{C}$ allele] $\mathrm{x}$ [male not carrying $* \mathrm{C}$ allele] but not of mating types [female carrying $* \mathrm{C}$ allele] $\mathrm{x}$ [male carrying $* \mathrm{C}$ allele].

Preliminary data on ACP1 maternal-neonatal distribution in normal puerperae from the population of Penne are shown in Table 5. There is an excess of the type [mother carrying $* \mathrm{C}$ allele] $\mathrm{x}$ [offspring not carrying $* \mathrm{C}$ allele].

\section{DISCUSSION}

The term habitual abortion is well established in clinical practice, although there is a considerable disagreement about its definition, since the existence of a separate population of women with high-risk pregnancies has not been proven unambiguously yet. Selecting couples with repeated abortions in our study has a definite advantage of identifying spontaneous abortions. Indeed, while the correct assignment of a single episode of abortion as spontaneous or induced is generally difficult, all of our cases are certainly spontaneous. It is also likely that inherited factors may have a relatively greater importance in women with consecutive spontaneous abortions than in women with a single episode of miscarriage in whom stochastic factors may be more prevalent. Comparison of repeated with sporadic abortion (Table 1) shows that the association with ACPl genotype is present only in habitual abortion thus supporting this conjecture.

The data in Table 1 indicates that women carrying ACP $1 * \mathrm{C}$ allele which shows the highest ACP1 activity, are less likely to have a clinical recognizable spontaneous abortion, suggesting a 'protective' effect by this allele. It could be argued, however, that, since clinically recognizable spontaneous abortions represent only a small fraction (probably less than $10 \%$ ) of the total loss of embryos during the intrauterine development (Chard, 1991), the 'protective' effect observed in women carrying an 
Table 3. Ratio of female carriers of $* \mathrm{C}$ allele to female non carriers in relation to carrier status of husband.

\begin{tabular}{c|c|c|c|}
\cline { 3 - 4 } \multicolumn{2}{c|}{ status of husband. } & \multicolumn{2}{c|}{ Husband } \\
\cline { 3 - 4 } \multicolumn{2}{c|}{ Wife } & carrier of ACP1*C allele & non carrier \\
\cline { 2 - 4 } & carrier of ACP1*C allele & 5 & 4 \\
\cline { 2 - 4 } & non carrier & 18 & 142 \\
\hline
\end{tabular}

per cent proportion of female carriers of
$*$ C allele
$21.7 \%$
$2.7 \%$

Fisher exact test

$\mathrm{p}<0.01$

Table 4. ACP1 mating type distribution in couples with repeated spontaneous abortions. Expected values have been calculated on the basis of $\mathrm{ACP} 1 * \mathrm{C}$ allele frequencies of normal controls (sample 5 of Table 1) and assuming Hardy-Weinberg equilibrium and random mating.

\begin{tabular}{|c|c|c|c|c|}
\hline \multirow{2}{*}{ mo. } & & & \multicolumn{2}{|c|}{ Husband } \\
\hline & & & not carrying $\mathrm{ACP} 1 * \mathrm{C}$ & carrier \\
\hline \multirow{4}{*}{ Wife } & \multirow[t]{2}{*}{ not carrying $\mathrm{ACP} 1 * \mathrm{C}$} & observed & 142 & 18 \\
\hline & & expected & 121.07 & 21.97 \\
\hline & \multirow[t]{2}{*}{ carrier } & observed & 4 & 5 \\
\hline & & expected & 21.97 & 3.99 \\
\hline
\end{tabular}

Table 5. ACP1 joint mother-infant type distribution in normal puerperae. Expected values have been calculated on the basis of mean value of $\mathrm{ACP} 1 * \mathrm{C}$ allele frequencies of mothers and newborns and assuming Hardy-Weinberg equilibrium.

\begin{tabular}{|c|c|c|c|c|}
\multicolumn{2}{c}{} & \multicolumn{2}{c|}{ Newborn } \\
\cline { 5 - 5 } \multicolumn{2}{c}{} & not carrying ACP $1 * \mathrm{C}$ & carrier \\
\hline \multirow{3}{*}{ Mother } & not carrying ACP1 1 C & observed & 283 & 19 \\
& & expected & 289.4 & 19.5 \\
& carrier & observed & 30 & 20 \\
& & expected & 19.5 & 23.6 \\
\cline { 2 - 3 } & & &
\end{tabular}

comparison of carrier mothers bearing a non carrier newborn vs other types 
$\mathrm{ACP} 1 * \mathrm{C}$ allele might, in fact, be a result of an earlier loss of zygotes that is not clinically recognizable.

The data in Tables 3 and 4 demonstrate that the distribution of ACP1 genotypes among women with habitual abortions is dependent on the ACP1 genotype of their husbands suggesting that the 'mating type' of a 'couple' might be the most important determinant of susceptibility to spontaneous fetal loss. In fact, comparing the observed frequencies with those expected under the null hypothesis of independence, it is seen that the 'protective' effect of a maternal $\mathrm{ACP} 1 * \mathrm{C}$ allele is present only if the husband does not carry such an allele. This suggests a preferential protection of foetuses not carrying $\mathrm{ACP} 1 * \mathrm{C}$. On the other hand, the analysis of the joint mother-infant distribution of ACP1 genotypes (Table 5 ) shows a statistically significant excess of $* A / * A, * A / * B$ and $* B / * B$ infants (i.e. not carrying the $\mathrm{ACP} 1 * \mathrm{C}$ allele) born by mothers carrying an $\mathrm{ACP} 1 * \mathrm{C}$ allele. Thus, these data on normal puerperae also support the hypothesis that foetuses not carrying $\mathrm{ACP} 1 * \mathrm{C}$ have a relatively high probability of survival if the mother carries an $\mathrm{ACP} 1 * \mathrm{C}$ allele.

It is likely that $* \mathrm{C}$ carrier mothers protect non-carrier zygotes during the early stages of development also. Only under such assumption, in fact, it is possible to explain the excess of newborns not carrying $\mathrm{ACP} 1 * \mathrm{C}$ among normal puerperae carrying this allele.

Our study of habitual abortion started before 1980 and was interrupted for a short period in 1987. The association with ACP1 is very similar between the two samples: in the first series ( 68 couples) the proportion of women carrying ACP1*C allele is $5.9 \%$ and in the second series (105 couples) $4.8 \%$.

Only $\mathrm{S}$ isoform is involved in the association with spontaneous abortion. This observation supports the conjecture that $\mathrm{F}$ and $\mathrm{S}$ isoforms may serve different biological functions.

The reproducibility of the pattern of association in samples collected in different times in the same population, the consistence of relevant aspects of assocation in different samples from diverse populations, and the specificity of association for only one ACP1 isoform make it very unlikely that the observed pattern may be due to mere sampling artefacts.

An association, however, does not represent the demonstration of a causal relationship. At present, the effect of other genes near ACP1 and in linkage disequilibrium with it cannot be excluded. However, the described association cannot be considered 'random'. In fact, we searched for it on the basis of 'a priori' knowledge of ACP1 functions which suggested relevance in intrauterine development, and we found a pattern of relationships consistent in independent samples and biologically plausible on the basis of the enzymatic properties of ACP1. Therefore, we are propense to consider ACP1 as causal in the association.

Protein-tryrosine phosphatases (PTPases), including ACP1, play an essential role in the control of a receptor signalling through the phosphotyrosine pathway. Since the phosphorylation state of critical target proteins is balanced by the action of kinases and phosphatases (Goldstein, 1992; Fischer et al., 1991; Hashimoto and Goldstein, 1992; Saad et al., 1992; Kahn and White, 1988), genetic variability of ACP1 enzymatic activity may influence the action of growth factors (Stefani et al., 1993), and, in turn, intrauterine development and survival. A modulation of the action of growth factors can be very critical in the early stages of development, when the genomic stability is probably reduced. The association of ACP1 genotype with spontaneous abortion as well as the 
associations with congenital fetal malformations (Ward et al., 1986) and intrauterine growth (Amante et al., 1990) support this hypothesis.

\section{ACKNOWLEDGEMENT}

This work was supported by CNR Grant No. 88.0339,111.

\section{REFERENCES}

Amante, A., Gloria-Bottini, F., Bottini, E. (1990). Intrauterine growth: association with acid phosphatase genetic polymorphism. J. Perinat. Med., 18, 275-282.

Boivin, P., Galand, C. (1986). The human red cell acid phosphatase is a phosphotyrosine protein phosphatase which dephosphorylates the membrane protein band 3. Biochem Biophys. Res. Comm., 134, 557-564.

Boklage, E. (1990)., Survival probabibility of human conceptions from fertilization to term. Int. J. Fertil., 35, 75-94.

Camici, G., Manao, G., Cappugi, G., Modesti, A., Stefani, M., Ramponi, G. (1989). The comple amino acid sequence of the low molecular weight cytosolic acid phosphatase. J. Biol. Chem., 264, 2560-2567.

Chakraborty, R., Ferrell, R.E., Barton, S.A., Schull, W.J. (1986). Genetic polymorphism and fertility parameters in the Aymara of Chile and Bolivia. Ann. Hum. Genet., 50, 69-82.

Chard, T. (1991). Frequency of implantation and early pregnancy loss in natural cycles. Bailliere's Clinical Obstetrics and Gynaecology, 5, 179-189.

Diamond, J.M. (1987). Causes of death before birth. Nature, 329, 487.

Dissing, J. (1987). Immunochemical characterization of human red cell acid phosphatase isozymes. Biochem. Genet., 25, 901-917.

Dissing, J., Johnsen, A.H., Sensabaugh, G.F. (1991). Human red cell acid phosphatase (ACP1). The amino acid sequence of the two isozymes $\mathrm{Bf}$ and $\mathrm{Bs}$ encoded by the $\mathrm{ACP} 1{ }^{*} \mathrm{~B}$ allele. J. Biol. Chem., 266, 20619-20625.

Dissing, J., Svensmark, O. (1990). Human red cell acid phosphatase: purification and properties of the A, B and C isozymes. Biochim. Biophys. Acta., 1041, 232-242.

Fischer, E.H., Charbonneau H., Tonks, N.K. (1991). Protein tyrosine phosphatases: a diverse family of intracellular and transmembrane enzymes. Science, 253, 401-406.

Fuchs, K.R., Shekels, L., Bernlohr, D.A. (1992). Analysis of the ACP1 gene product: classification as a FMN phosphatase. Biochem. Biophys. Res. Comm., 189, 1598-1605.

Goldstein, B.J. (1992). Protein-tyrosine phosphatases and the regulation of insulin action. J. Cell. Biochem., 48, 33-42.

Harris, H., Hopkinson, D.A. (1976). Handbook of Enzyme Electrophoresis in Human Genetics, Amsterdam, North Holland.

Hashimoto, N., Goldstein, B.J. (1992). Differential regulation of mRNA encoding three proteintyrosinephosphatases by insulin and activation of protein kinase C. Biochem. Biophys. Res. Comm., 188, 1305-1311.

Hicks, J.B. (1987). Mechanism of differentiation. Nature, 326, 444.

Kahn, C.R., White, M.F. (1988). The insulin receptor and the molecular mechanism of insulin action. J. Clin. Invest., 82, 1151-1156.

Manao, G., Pazzagli, L., Cirri, P., Caselli, A., Camici, G., Cappugi, G., Saeed, A., Ramponi, G. (1992). Rat liver low Mr phosphotyrosine protein phosphatase isoenzymes: purification and amino acid sequences. J. Protein Chem., 11, 333-345.

Mansfield, E., Sensabaugh, G.F. (1978). Red cell acid phosphatase: modulation of activity by purines. In: Brewer, G.F. (Ed.), The Red Cell. New York, Lisse, 1978, pp. 233-247.

Modiano, G., Filippi, G., Brunelli, F., Frattaroli, W., Siniscalco, M. (1967). Studies on red cell acid 
phosphatase in Sardinia and Rome. Absence of correlation with past malarial morbidity. Acta Genet., Basel, 17, 17-28.

Nie, N.H., Hull, H.C., Jenkins, J.G., Steinbrenner, K., Bent, D.H. (1975). Statistical Package for the Social Sciences. Second edition. McGraw-Hill Book Company, Chicago.

Ramponi, G., Manao, G., Camici, G., Cappugi, G., Ruggiero, M., Bottaro, D.P. (1989). The 18 $\mathrm{kDa}$ cytosolic acid phosphatase from bovine liver has phosphotyrosine phosphatase activity on the autophosphorylated epidermal growth factor receptor. Febs Letters, 250, 469-473.

Ramponi, G., Rugiero, M., Raugei, G., Berti, A., Modesti, A.A., Degl'Innocenti, D., Magnelli, L., Pazzagli, C., Chiarugi, V.P., Camici, G. (1992). Overexpression of a synthetic phosphotyrosine protein phosphatase gene inhibits normal and transformed cell growth. Int. J. Cancer, 51, 652656.

Saad, M.J.A., Araki, E., Miralpeix, M., Rothenberg, P.L., White, M.F., Kahn, R. (1992). Regulation of insulin receptor substrate-1 in liver and muscle of animal models of insulin resistance. J. Clin. Invest., 90, 1839-1849.

Spencer, N., Hopkinson, D.A., Harris, H. (1964). Quantitative differences and gene dosage in the human red cell acid phosphatase polymorphism. Nature, 201, 299-300.

Stefani, M., Caselli, A., Bucciantini, M., Pazzagli, L., Dolfi, F., Camici, G., Manao, G., Ramponi, G. (1993). Dephosphorylation of tyrosine phosphorylated synthtic peptides by rat liver phosphotyrosine protein phosphatase isoenzymes. FEBS, 326, 131-134.

Vogel, W., Lammers, R., Huang, J., Ullrich, A. (1993). Activation of a phosphotyrosine phosphatase by tyrosine phosphorylation. Science, 259, 1611-1614.

Vogel, F., Motulsky, A.G. (1986). Human Genetics. Springer Verlag, Berlin.

Ward, R.D., Sarfarazi, M., Azimi-Garakani, C., Beardmore, J.A. (1986). Genetic polymorphisms and a search for genetic influences on morbidity in the newborn. In: Harper, P.S., Sunderland, E. (Eds.), Genetic and Population Studies in Wales. Cardiff, University of Wales Press, 1986, p. 342.

Wo, Y.P., McCormack, A.L., Shabanowitz, J., Hunt, D.F., Davist, J.P., Mitchell, G.L., Van Etten, R.L. (1992). Sequencing, cloning and expression of human red cell-type acid phosphatase, a cytoplasmic phosphotyrosyl protein phosphatase. J. Biol. Chem., 267, 10856-10865. 


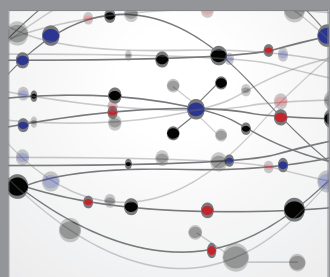

The Scientific World Journal
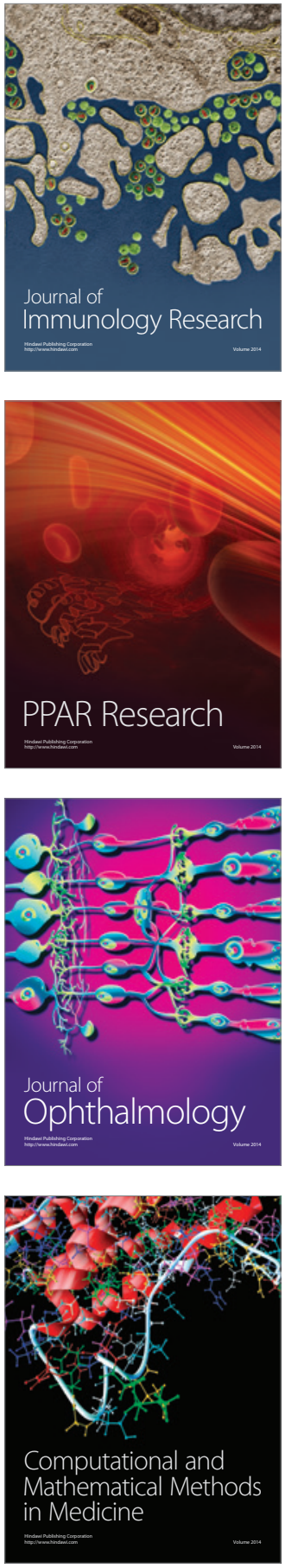

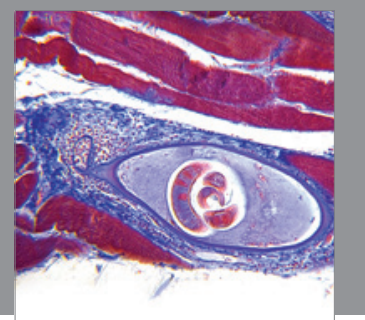

Gastroenterology

Research and Practice
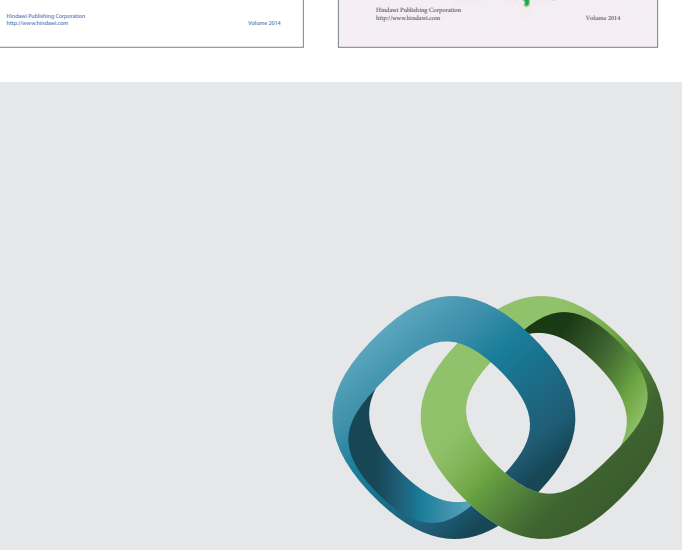

\section{Hindawi}

Submit your manuscripts at

http://www.hindawi.com
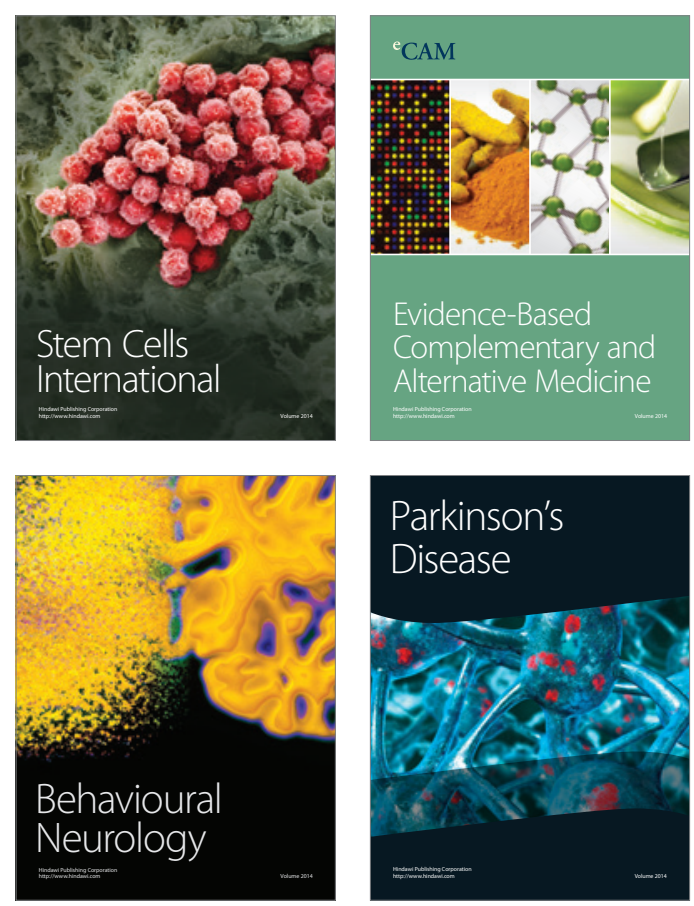

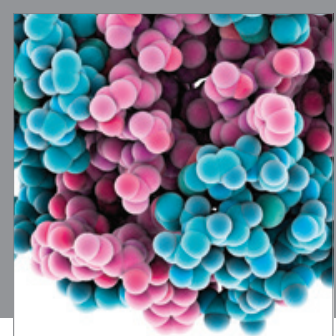

Journal of
Diabetes Research

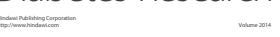

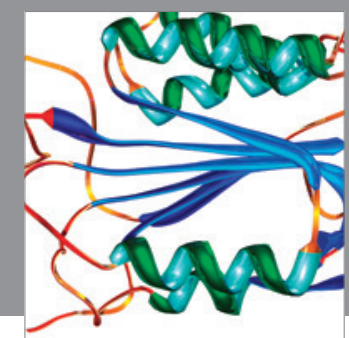

Disease Markers
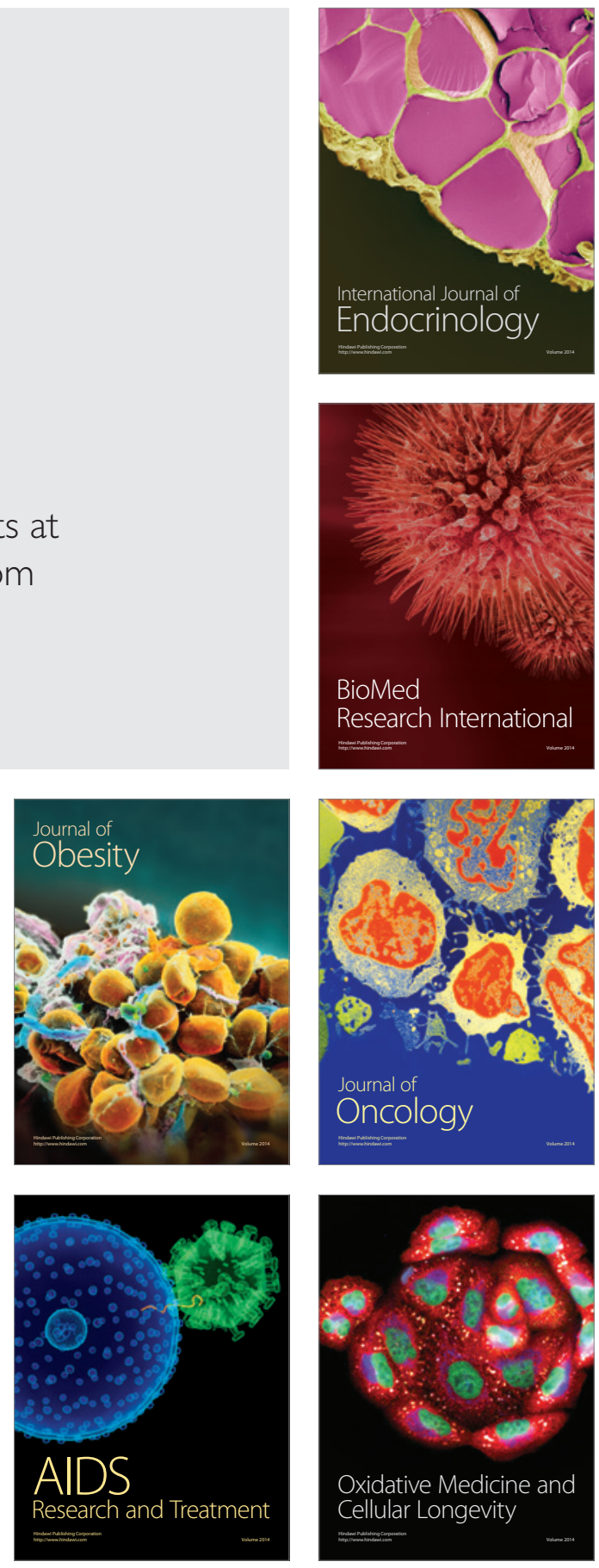